ISSN 1392-3196 / e-ISSN 2335-8947

Zemdirbyste-Agriculture, vol. 101, No. 1 (2014), p. 91-100

DOI 10.13080/z-a.2014.101.013

\title{
Species ratio, spring emergence, population dynamics and damage of plum sawflies Hoplocampa minuta and $\mathrm{H}$. flava in plum orchard
}

\author{
Rimantas TAMOŠIŪNAS, Alma VALIUŠKAITĖ, Elena SURVILIENĖ, \\ Neringa RASIUKEVIČIŪTĖ \\ Institute of Horticulture, Lithuanian Research Centre for Agriculture and Forestry \\ Kauno 30, Babtai, Kaunas distr., Lithuania \\ E-mail: r.tamosiunas@1sdi.lt
}

\begin{abstract}
An investigation of black plum sawfly (Hoplocampa minuta Christ, 1791) and yellow plum sawfly (Hoplocampa flava Linnaeus, 1761) populations using white sticky traps Rebell ${ }^{\mathbb{Q}}$ bianco was carried out in a plum orchard of Institute of Horticulture of Lithuanian Research Centre for Agriculture and Forestry from 2010 to 2012. A possibility to predict spring emergence of $H$. minuta and $H$. flava using temperature sum method, species ratio, main population parameters and relation between trap catches and infestation levels were investigated. $H$. minuta appeared to be more dominant in the complex of two plum sawfly species during the study overall, building up to $62 \%$ of individuals in comparison to $H$. flava and, considering various population parameters (emergence and flight dynamics, population density, sex ratio) being more significant contributor to fruit damage. Population density and flight dynamics were driving factors in determining potential damage to crop. Coincidence between mass flight and flowering periods was one of the major factors influencing fruit damage caused by plum sawflies. When mass flight coincided with flowering phase, vulnerable to sawfly attack of plum cv. 'Stanley', a high damage level of $27.8 \%$ was observed. When mass flight was strongly shifted towards the end of flowering, a relatively low damage of $7.0 \%$ was recorded. Based on the results of the correlation analysis, trap catch data could be reliably used to predict the magnitude of fruit damage level only when mass flight coincides with susceptible flowering phase. Further studies are needed to establish reliable damage thresholds for different plum cultivars. Temperature sum model to predict emergence of first plum sawfly adults was proposed. The model was based on soil temperature at $10 \mathrm{~cm}$ depth and two different starting dates to begin calculation. Temperature sums of 86 and 84 degree-days were calculated. Provisionary date at a temperature sum of 60 degree-days is proposed for trap placement in the orchards.
\end{abstract}

Key words: plum sawflies, population dynamics, temperature sum model, white sticky traps.

\section{Introduction}

Fruits of plum trees are attacked by two species of sawflies - black and yellow plum sawflies (Hoplocampa minuta Christ 1791 and H. flava Linnaeus, 1761) and both species are considered to be among the most dangerous pests of plum fruits. Problems related to heavy infestations of plum sawflies have been reported from all plum cultivation areas in Western, Central, Eastern and Northern Europe (Bovien, Stapel, 1940; Hadzistevic, 1959; Nagy, 1959; Arnaoudov, Andreev, 2002; Jaastad et al., 2007; Oroian et al., 2009; Andreev, Kutnikova, 2010). They are monovoltine species which spend most of their life-cycle as diapausing larvae in the soil. In Lithuanian conditions, both species emerge around the beginning of May and beginning of flight coincides with the start of flowering of early plum varieties. The females lay eggs into the calyxes of blossoms and larvae hatch when fruits begin to develop. During the course of feeding larvae leave damaged fruit and burrow into intact one. As a result one larva can destroy up to five fruitlets. Damaged fruitlets fall off. Both species mainly are found together, but $H$. minuta is considered to be dominant and contributes to the most of the damage caused. If conditions for the sawfly development are favourable and no control measures are taken it could result in almost complete destruction of the crop (Leski, 1960; Blaisinger, 1974). According to different authors, the extent of damage on various plum cultivars may reach up to 55-96\% (Oroian et al., 2009; Andreev, Kutnikova, 2010; Rozpara et al., 2010).

Plum sawfly management tactics are based on the use of synthetic insecticides. Most studies demonstrated a good efficacy of all insecticides against closely related apple sawfly (Hoplocampa testudinea Klug, 1816) species (Ciglar, Barić, 2002). In Lithuania, 
mainly broad-spectrum pyrethroids or neo-nicotinoids with contact mode of action are used to reduce apple and plum sawfly damage. One or two insecticide treatments - before the flowering and during the petal fall are usually applied against plum sawflies. Various studies demonstrated that performance of insecticides primarily depended on the accurate timing of treatments (Wildbolz, Staub, 1984). The peak of sawfly flight and egg-laying usually coincides with flowering period of plum trees when use of insecticides is not allowed. Thus, the pre-bloom applications aimed at controlling sawfly adults often may not reach the target. Application during petal fall aimed at hatching sawfly larvae is considered to be the most important by most authors (Bovien, Stapel, 1940; Leski, 1960; Graf et al., 1996 a; b; 2001; 2002; Ciglar, Barić, 2002). Shortly after hatching from the egg, larva penetrates into the fruitlet and becomes well protected from contact insecticides. This short susceptible period between hatching and penetrating into the fruit is of critical importance in management of plum sawflies. In Lithuania, the first steps towards the integrated horticultural pest management are being implemented. Integrated pest management (IPM) requires deep knowledge of biology, ecology and phenology of target species. Only then reliable action thresholds can be determined. Many factors (biotic and abiotic) can influence the dynamics of plum sawfly populations by directly or indirectly affecting survival and development rates or female fecundity. Thus, a good understanding of under what circumstances control measures should be used is necessary. Several useful tools have been developed for monitoring of apple and plum sawfly populations. White sticky traps are used to monitor the beginning and activity of flight of sawfly adults (Owens, Prokopy, 1978; Wildbolz, Staub, 1984). Phenology models for predicting apple sawfly spring emergence, adult life span, egg-laying activity and egg-hatch were developed by Graf et al. (1996 a; 2001; 2002). In addition, a model to predict possible infestation levels of black plum sawfly with respect to environmental conditions was presented (Шевчук, Денисюк, 2009).

The aim of this field study was to investigate the possibility to predict spring emergence of $H$. minuta and $H$. flava using temperature sum method, examine species ratio, population dynamics and determine a relation between trap catches and infestation levels in Central Lithuania.

\section{Materials and methods}

Field work was completed at experimental apple and plum orchards of Institute of Horticulture, Lithuanian Research Centre for Agriculture and Forestry in Central Lithuania $\left(55^{\circ} 4^{\prime} \mathrm{E}, 23^{\circ} 48^{\prime} \mathrm{N}\right)$ in three consecutive seasons from 2010 to 2012. Plum sawfly (Hoplocampa minuta, H. flava) populations were surveyed in a plum orchard consisting mostly of different plum hybrids planted in 4-tree plots and arranged in random order. Investigation was conducted on cv. 'Stanley' planted in three rows and positioned near the edge of the orchard. They were productive five-year old trees in 2010. 'Stanley' was a late blooming plum variety. Rows were oriented North-EastSouth-West direction. Length of rows was approximately $420 \mathrm{~m}$ and the area of an experimental plot ca. 0.5 ha. Pruning, shaping and care of plum cv. 'Stanley' were maintained as recommended, the grass on alleys between rows was repeatedly mown and fungicides against main diseases were applied during the period of the study.

White sticky traps Rebell ${ }^{\circledR}$ bianco ("Andermatt Biocontrol", Switzerland) were used to monitor sawfly flight activity and population density. In 2010 and 2012, four traps in plum orchard were arranged throughout three rows - two were placed closer towards the end and two towards the centre of the rows at 30-50 m distances. In 2011, five traps were arranged throughout the rows in similar fashion. Traps were hung on branches or at the height of 1.6-1.7 $\mathrm{m}$ on the external south part of the tree canopy. In every year of the survey, white sticky traps were installed in the orchards in third quarter of April. Traps remained effective for entire flight period of adult sawflies and those heavily filled with other insects were replaced once per sampling period in order to retain efficacy. In order to determine the beginning of adult sawfly flight period, traps were inspected every two days. After catching the first sawflies, traps were checked once per week in 2010 and every 1-3 days in 2011 and 2012. Sawfly adults were counted and removed from the traps, then sexed ex situ in the laboratory by using microscope. On-tree fruit injury surveys were performed before fruitdrop by visual examination. A hundred (or 50 if fruit setting was low) fruits per tree were selected randomly from lower, central and upper parts of the tree canopy for damage assessment. Trees for fruit sampling were chosen at random.

Daily temperatures were recorded at $10 \mathrm{~cm}$ under the ground and $150 \mathrm{~cm}$ above ground, by iMetos ${ }^{\circledR}$ weather station ("Pessl Instruments", Austria), located at the experimental apple orchard of Institute of Horticulture, Lithuanian Research Centre for Agriculture and Forestry, ca. $0.8 \mathrm{~km}$ from the experimental site. Beginning of sawfly flight was compared to a temperature sum model proposed by Zijp and Blommers (1997), where day-degree accumulation was started on different dates. Effective temperature sums were calculated using sinusoid between daily minimum and maximum temperatures as was proposed by Rabbinge (1976) and successfully adapted to predict sawfly adult spring emergence by Zijp and Blommers (1997). Thermal threshold of $4^{\circ} \mathrm{C}$ was used in the calculation and two dates for starting of calculation were used: first day when the thermal threshold was reached and on fixed date of 1 April.

To detect differences between temperature sums its variances were compared using an $F$-test. Trap catch data (population density) and total sum of trap catches between years were compared by the means of a $t$-test or non-parametric Mann-Whitney test when data was not normally distributed. Infestation levels were expressed as percentage and calculated using formula: $\frac{A}{B} \times 100$, where $\mathrm{A}$ is infested fruit on certain cultivar, 
B - overall fruit sampled on certain cultivar. Sawfly density data was expressed as mean value per trap and standard errors of the mean were also provided. The relationships between trap catches and infestation levels and between main flowering season and main flight period of sawfly related to infestation level were calculated by the means of non-parametric Spearman ranked correlation analysis (Zar, 2010). All statistical routines were performed using statistical software package Sigmaplot (Systat Software, USA).

\section{Results and discussion}

Species ratio, population density and sex ratio of both species. Numbers of Hoplocampa minuta and $H$. flava adults caught on traps varied considerably between years of the study. Proportion of black and yellow sawflies was slightly biased towards $H$. minuta (Fig. 1). In 2010 and 2012, numbers of adult sawflies of both species caught were similar $-H$. minuta constituted $53 \%$ and $52 \%$ of two species and significant differences in trap catches between two species were not detected (Mann-Whitney and $t$-test, $p>0.05$ ). In 2011, the ratio was strongly biased towards black plum sawflies - almost $77 \%$ of adults caught were $H$. minuta and statistical analysis demonstrated that significantly more adults of black plum sawfly were caught $(t$-test, $p<0.05)$. H. minuta appeared to be more dominant in the complex of two plum sawfly species during the study overall, building up to $62 \%$ of individuals in comparison to $H$. flava. Most authors reported $H$. minuta being clearly dominant of two plum sawfly species in continental part of Europe and as a result being a major contributor to fruit damage (Leski, 1960; Arnaoudov, Andreev, 2002; Caruso, Cera, 2004; Jaastad et al., 2007; Шевчук, Денисюк, 2009). On the contrary, as reported in the study performed in Emilia Romana region in Italy, H. flava was the most widespread species (Molinari et al., 1996). Studies on Lithuanian sawfly fauna in plum orchards (Stanionytè, Zajančkauskas, 1970) demonstrated the trend of $H$. minuta being dominant and $H$. flava only satellite species. In the present study, it appeared that the two sawfly species were equally important plum pests in Lithuania as their ratio in plum orchard agrocenosis was very close during three years of the survey.

The overall cumulative density of $H$. minuta adults fluctuated significantly during the course of the study. In 2010, cumulative density of $H$. minuta reached $14.8 \pm 3.6$ sawfly $\operatorname{trap}^{-1}$ (Fig. 2). Meanwhile in 2011 black sawfly density was the highest during the study and reached $54.2 \pm 16.1$ sawfly trap $^{-1}$ significantly exceeding that in 2010 ( $t$-test, $p<0.05$ ). In 2012 density of 24.5 \pm 8.9 sawflies trap ${ }^{-1}$ was recorded and did not differ significantly from 2010 and 2011 ( $t$-test, $p>0.05$ ). On the contrary, cumulative density of adult $H$. flava sawflies was constant and varied only slightly during all years of the investigation. In 2010, 2011 and 2012 respectively cumulative trap catches of $13.3 \pm 2.6$ sawflies trap ${ }^{-1}, 16.6$ \pm 3.1 sawflies trap ${ }^{-1}$ and $22.5 \pm 6.0$ sawflies trap $^{-1}$ were recorded and no significant differences between them were

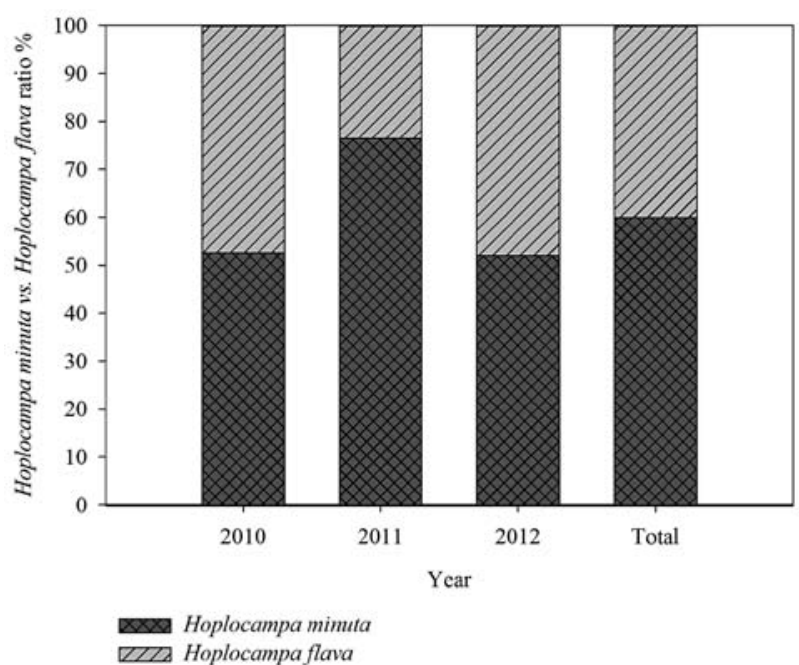

Figure 1. Ratio of black to yellow plum sawfly species in the investigated populations in 2010-2012

detected ( $t$-test, $p>0.05$ ). For practical purposes, such as infestation prognosis and decision making procedures, it is more important to know total population density of both plum sawfly species together. The highest density of both species was recorded in 2011, when cumulative trap catches of $70.8 \pm 18.2$ sawflies trap ${ }^{-1}$ was reached. The lowest numbers of $H$. minuta and $H$. flava were caught during 2010 adult sawfly flight period - 29.8 \pm 5.4 sawflies trap $^{-1}$. In 2012, relatively high $-47.0 \pm$ 14.6 sawflies trap ${ }^{-1}$ density was recorded. Use of sticky traps is a relative means of population measurement and interpretation of trap catches is very difficult as trap counts are strongly influenced by trap type, design, and density in orchards as well as various environmental factors (Southwood, Henderson, 2007). Nevertheless, if sufficient coverage of traps is ensured, white sticky traps can provide useful information on sawfly population relative density, distribution, and dynamics in particular area. If same distances and positioning for trap placement is provided, trap catch data from different localities can be compared and provide useful insights on sawfly populations. White sticky traps were proved to be attractive to sawflies of both sexes at relatively short distances (up to 75 meters) and also reliably represented actual numbers of newly emerging plum and closely related species - apple sawfly (H. testudinea Klug) (Wildbolz, Staub, 1984). In the present study, relative cumulative density of black plum sawfly adults during flight period in different years was highly variable. This variability could be attributed mainly to biological reasons and environmental conditions during egg-laying larval development and overwintering periods. Several authors reported prolonged winter diapause in apple sawfly (H. testudinea) populations when overwintering larvae remain in the soil for two or three winters (Kuenen, van de Vrie, 1951, Zijp, Blommers, 2002). Prolonged diapause insures the apple sawfly against elimination of a year class of its host (Tauber, Tauber, 1976), when, for example, fruitlets are destroyed by late frost or other causes. Prolonged diapause was also observed in $H$. minuta populations and 
it suggested this biological trait was common in black plum sawfly populations as well (Hadzistevic, 1959; Leski, 1960). Another reason which may have impact on fluctuations in plum sawfly population density could be mortality of sawfly larvae caused by biotic (parasitoids and fungal diseases) and climatic factors. No papers are published on parasitoids exploiting black and yellow plum sawflies as hosts. Entomophagous fungi may also contribute to high mortality of plum sawflies in soil as has been reported in numerous studies on closely related apple sawfly species (Niezborala, 1978; Jaworska, 1992). However, influence of parasitoids and fungi on populations of plum sawflies was not within scope of this study and has not been quantified. Data acquired in the present study also demonstrated that density of $H$. flava populations varied less in different years than that of $H$. minuta. It suggests that some factor limiting density only of $H$. minuta populations is involved. This study also revealed highly heterogeneous distribution of plum sawfly populations. High standard error scores of trap catch means, especially those in $H$. minuta, demonstrates big differences between numbers of sawfly adults caught on every individual trap. This data reveals that even in relatively small area of experimental plot sawfly adults aggregated in certain places. Thus, it can be concluded that plum sawfly populations are clustered and concentrated in several particular places throughout the orchard where they emerge from the soil. It was shown by Graf et al. (1996 b) in mark-release-recapture experiment that apple sawflies were reluctant to fly longer distances and were mostly recaptured in the range of $12 \mathrm{~m}$. It indicates that females tend to lay eggs on the trees which are in close proximity to the place of emergence. Therefore, population aggregation factor must be taken into account when considering overall infestation and management decisions. Unlike $H$. minuta, spatial distribution of H. flava appeared to be homogenous, probably due to

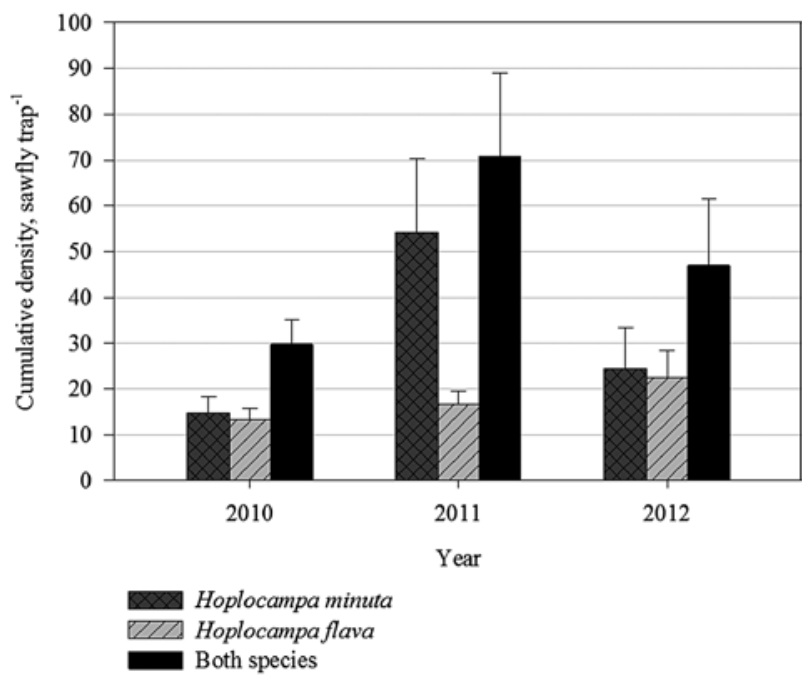

Figure 2. Cumulative density of plum sawfly species on plum cv. 'Stanley' in 2010-2012

lower density, indicating sawflies of this species to be distributed more equally throughout the orchard.

Another important parameter of sawfly populations is female to male ratio as potential damage levels can be attributed only to female portion of the population. Knowing sex ratio of particular insect population is also important to evaluate fitness and state of this population. Female ratio indicates reproductive potential of population and subsequently potential damage to the crops. Variability in sex ratios should be taken into account when trying to establish relationship between overall number of sawflies caught on traps and percentage of infested fruits. During the present study sex ratio of $H$. minuta and $H$. flava populations was slightly biased towards females (Fig. 3). Female percentage during the study was higher but also more variable in black plum sawfly population and reached 58,50 and $75 \%$ in 2010 , 2011 and 2012, respectively. On the contrary, sex ratio in
Hoplocampa minuta

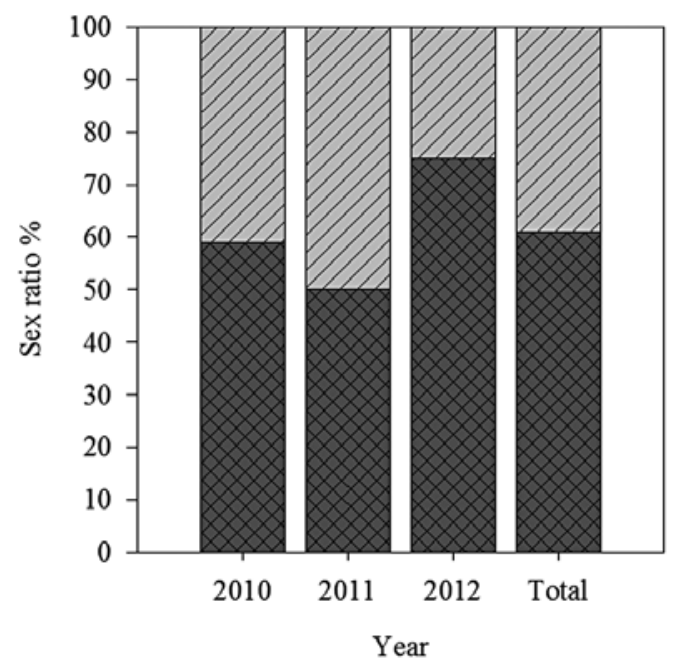

Female percentage एZC Male percentage
Hoplocampaflava

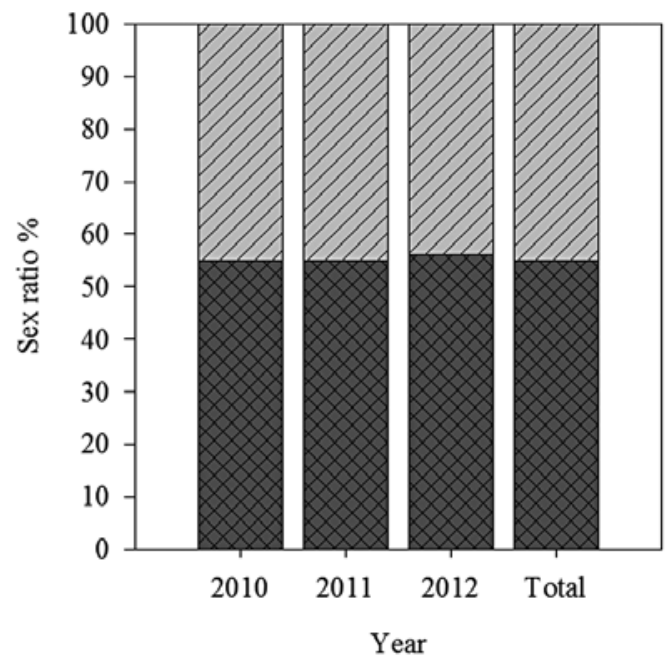

Figure 3. Sex ratio (percentage of females) of plum sawfly species in 2010-2012 
yellow plum sawfly population was constant during the study and females accounted for $55 \%$ of the population over three years of the survey. Usually sex ratio in sawflies of various species is strongly biased towards females and parthenogenesis is common. Nevertheless, it seems in hoplocampid sawflies sex ratio is close to $1: 1$ with slight bias towards females as pointed out by several authors (Leski, 1960; Molinari et al., 1996). Our study further supports this knowledge.

Emergence of adult sawflies, flight activity and coincidence with host plant growth stages. Slight differences were also observed in spring emergence dates and flight dynamics between $H$. minuta and H. flava during three study years. In 2010, first adults of $H$. minuta were caught on 1 May (day 121) and first adults of $H$. flava three days later - on 3 May (day 123) (Tables 1-2, Fig. 4). Flight period lasted 24 days for $H$. minuta and 21 day for $H$. flava. Increase in numbers of adults was more constant for $H$. minuta - trap catches increased steadily from emergence until mass flight stage (from $25 \%$ to $75 \%$ of cumulative density) was reached. Mass flight took place for 10 days from 9 to 18 May. Meanwhile density of $H$. flava increased slowly and mass flight period was very brief - from 15 to 19 May.

Table 1. Day of the $1^{\text {st }}$ capture and different mass flight stages (expressed in $\%$ of cumulative trap catches) of plum sawfly species

\begin{tabular}{lllllll}
\hline \multirow{2}{*}{$\begin{array}{c}\text { Day of the } 1^{\text {st }} \text { capture and } \\
\text { cumulative trap catches of adults }\end{array}$} & \multicolumn{3}{c}{ Hoplocampa minuta } & \multicolumn{3}{c}{ Hoplocampa flava } \\
\cline { 2 - 7 } & 2010 & 2011 & 2012 & 2010 & 2011 & 2012 \\
\hline Day of the $1^{\text {st }}$ capture of adults & 0105 & 2604 & 2904 & 0305 & 2704 & 2704 \\
$25 \%$ of cumulative flight & 0905 & 0205 & 0205 & 1505 & 2904 & 2904 \\
$50 \%$ of cumulative flight & 1505 & 1105 & 0405 & 1705 & 0605 & 0105 \\
$75 \%$ of cumulative flight & 1805 & 1205 & 0505 & 1905 & 1305 & 0405 \\
\hline
\end{tabular}

In 2011, warm and sunny weather conditions in last quarter of April resulted in higher soil temperatures. Subsequently, emergence of first adults of $H$. minuta and H. flava occurred 3-4 days earlier than in 2010 and coincided with 26 (day 116) and 27 (day 117) April, respectively. However, unlike in 2010, population of H. flava reached its peak density more rapidly and mass flight period was more prolonged in time than that of H. minuta. In 2012, the patterns of population dynamics remained rather similar as compared to 2011 . Due to extremely warm last days of April adults of both sawfly species also started to emerge almost at the same date as in 2011 - first adults of H. minuta and H. flava were caught on 29 April (day 120) and 27 April (day 118). Population growth of adults of both species was very rapid and brief in time. Population maximum was

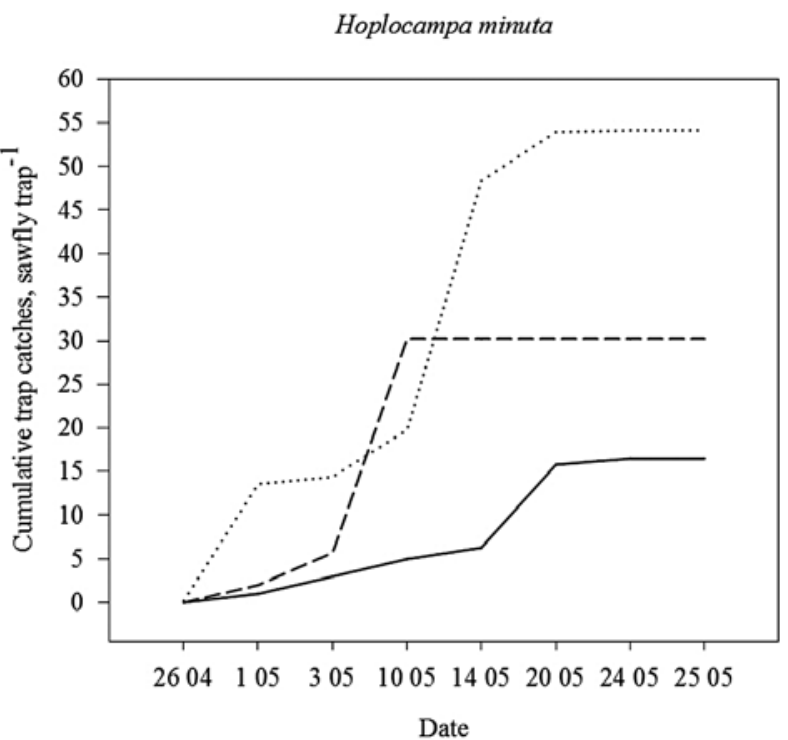

reached on 2 to 5 May for $H$. minuta and 1 to 4 May for $H$. flava and it was the fastest population increase during the study. It was also the shortest flight period for both species during the study and it took just 17 and 18 days for $H$. minuta and $H$. flava, respectively. Rapid increase in numbers of adults and very short flight period were probably influenced by uncommonly hot weather in the end of April and first half of May. These results indicate a very concentrated flight period of both species of plum sawflies. Phenology of both species is closely related, though mass emergence and flight of $H$. flava were earlier and more concentrated than of $H$. minuta. Supposedly, temperature requirements of $H$. flava may be lower as species is adapted to phenology of earlier blooming plum cultivars, yet it has to be proven experimentally.

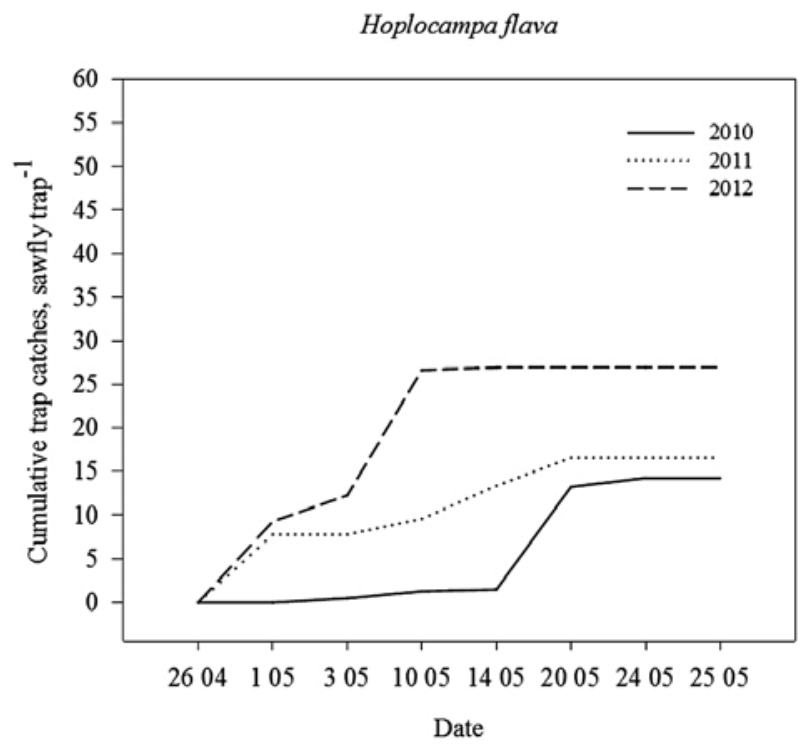

Figure 4. Cumulative flight curves indicating different population increase patterns of plum sawfly species in 2010-2012 
An important factor that influences potential damage to the fruits is coincidence of mass flight period of sawfly adults with the main flowering phase of its host plant. Life history of black and yellow plum sawflies, like of other oligophagous Hoplocampa spp. species, is best suited for exploiting resources that are predictable in time and space; however, resources are only available during a short period of the year. A close adaptation of their biology to the flowering and fruiting pattern of the host and precision in seasonal synchronization are more important than high reproductive potential and high mobility. Adult emergence and life span are closely correlated with host plant phenology (Boller, Prokopy, 1976). In 2010, flowering period of cv. 'Stanley' started from 3 May and continued until 12 May (Fig. 5). The beginning of mass flight stage of $H$. minuta was shifted towards the end of the flowering, meanwhile peak density period of $H$. flava was very short and started after the flowering of 'Stanley' had finished. Such disagreement between phenology of an insect and its host plant could be explained by different temperature sum accumulation in the air and soil. Phenology of plum trees is influenced mainly by air temperature, and rate of pupal development of $H$. flava and $H$. minuta is determined by soil temperature. In 2010, air temperature increased very rapidly but increase of soil temperature at $10 \mathrm{~cm}$ depth was much slower and it resulted in lagged accumulation of thermal energy required to complete pupal development of the insects. As a result, peak density of the pest populations was reached at the end of flowering period. As reported by several authors (Nagy, 1959; Leski, 1960), most susceptible phenological phase of plums to $H$. minuta and $H$. flava attack is a few days prior to and at the very beginning of flowering (BBCH 59-60, according to Meier et al., 1997). Delayed mass flight and egg-laying periods in 2010 was a result of unfavourable weather during the first half of May. Usually, when the weather conditions are cloudy, rainy and windy sawflies remain inactive even though population densities are high (Шевчук, Денисюк, 2009).

Subsequently, due to unfavourable climatic conditions during sawfly-susceptible phenological phase of cv. 'Stanley', mass flight as well as egg-laying periods were shifted towards the end of the flowering and resulted in reduced infestation (as will be discussed later in this text, Fig. 6). Additionally, from the flight curves it becomes clear, that in 2010 mainly $H$. minuta contributed to fruit damage as mass swarming of $H$. flava was extremely late. On the contrary, in 2011 flowering of 'Stanley' was delayed and started on 10 May and continued until 16 May. This could be explained by slow temperature sum accumulation in the air. As a result, soil temperature increased slowly, but without delay and, consequently, the beginning of flight and mass emergence of sawfly adults was early and populations reached their peak densities prior to onset of flowering (BBCH 57-59) of the host plant. In 2012, early emergence of first adults and fast population growth afterwards resulted in exact coincidence of peak density period of black and yellow
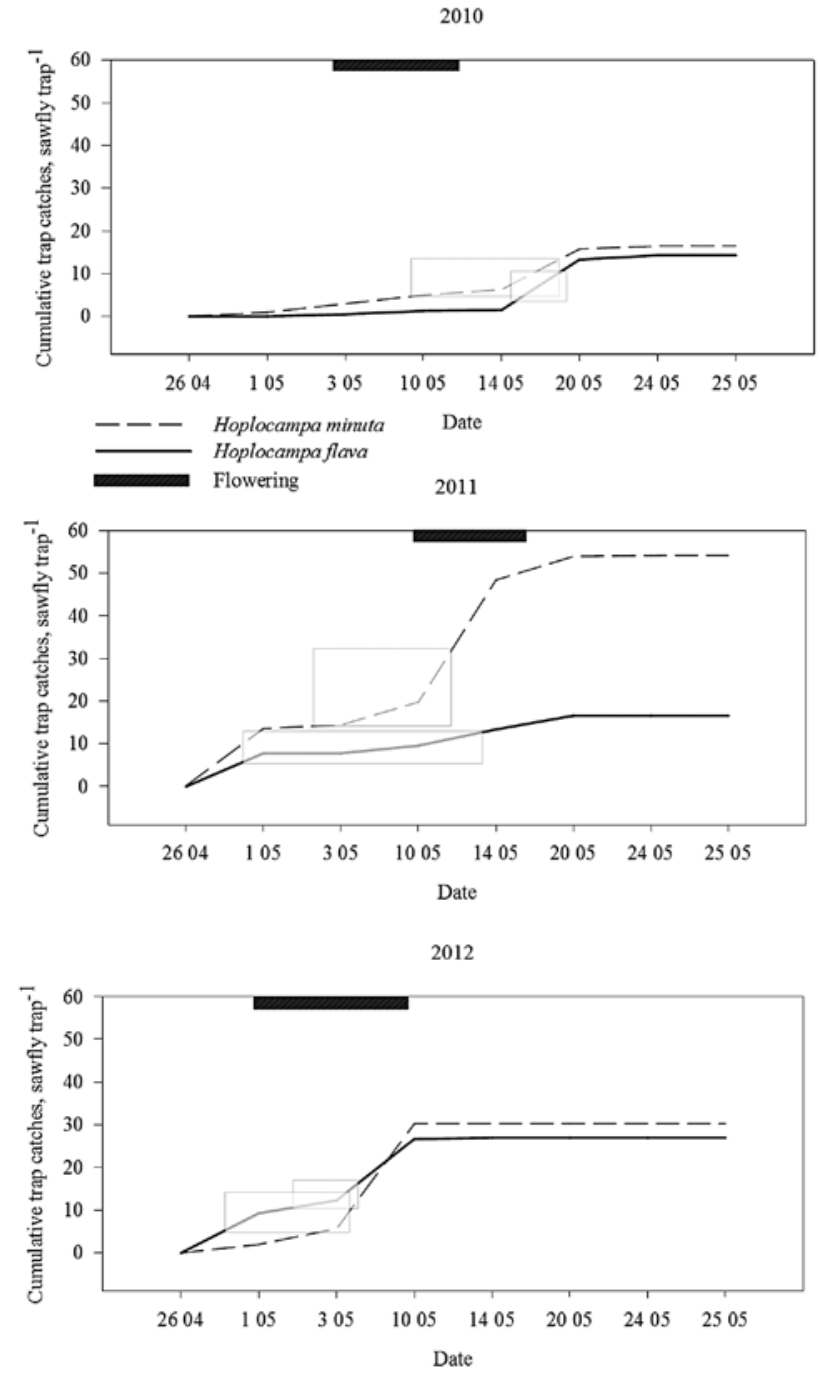

Note. Rectangles represent mass flight period of both sawfly species (25-75\% of cumulative trap catches).

Figure 5. Coincidence of mass flight period (25-75\% of cumulative density) of plum sawfly species and flowering phase of plum cv. 'Stanley'

plum sawflies with main flowering phase (BBCH 59-63) of cv. 'Stanley'.

Crop damage and relationship between coincidence of phenology of pest and its host plant and population density. Infestation caused by both plum sawfly species varied between years (Fig. 6). In 2010, percentage of damaged fruits was rather low and reached $7.0 \%$. Conversely, in 2011 significantly more damaged fruits were observed, infestation level reaching $27.8 \%$ and statistical difference between years was detected (Mann-Whitney test, $p<0.05$ ). In 2012, unfortunately, due to technical mismanagement, the pre-bloom insecticide treatment was applied to the experimental plot and therefore data on infestation levels was impossible to compare to previous years. In 2010 and 2011, flower setting of plum cv. 'Stanley' was equally high and could not have had strong influence on infestation levels. Therefore, two other major factors determining damage to the fruits were involved: population density (trap 


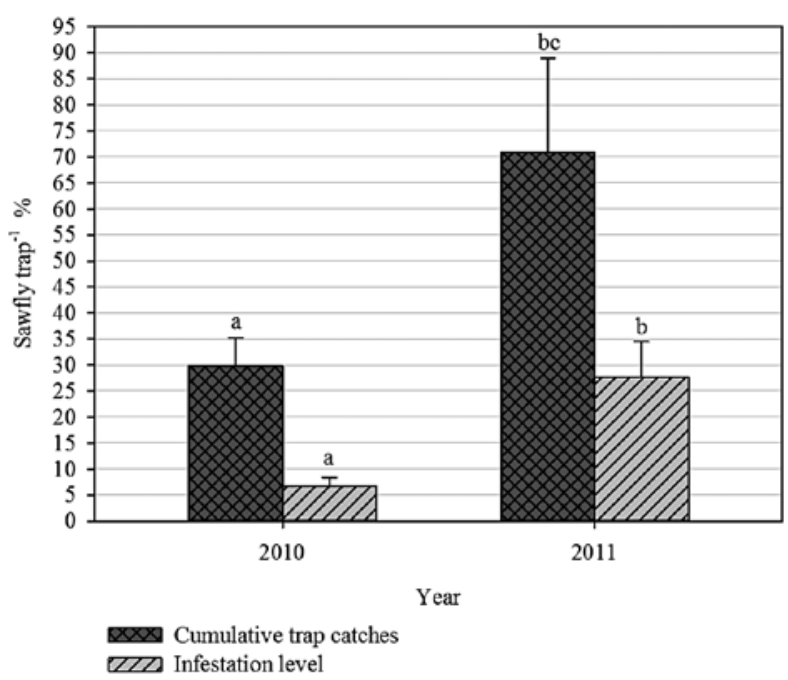

Notes. Letters denote statistical differences ( $t$-test, $p<0.05)$. The bars which have a different letter differ significantly (comparisons are made only within the same categories between different years)

Figure 6. Cumulative density of sawfly adults of both species during flight period and percentage of damaged fruits in different years of the study

catches) and coincidence of mass flight period and main flowering phase. No significant correlation $(r=0.527$, $p>0.05$ ) between trap catches and percentage of damaged fruit was detected in 2010. However, in 2011 strong relationship $(r=0.942, p<0.001)$ between two variables was determined, meaning that numbers of damaged fruits increased with higher population density (trap catches). These differences in no relationship and strong relationship between years supposedly were influenced by coincidence of mass flight period and flowering phase. Correlation analysis was performed to test the possible relationship between main flowering period and main flight period of plum sawflies related to infestation level. Analysis demonstrated significant moderate correlation between two factors $(r=0.630, p<0.001)$. In 2010, the beginning of mass flight period of $H$. minuta coincided with the very end of flowering of cv. 'Stanley' and mass flight of $H$. minuta began after the petal fall phase, when sawfly egg-laying was not possible. Therefore, sawfly population density during susceptible flowering phase was low and it resulted in lower infestation level.

For pest management purposes some advisory damage thresholds would be useful in order to predict possible harm to the crop. According to study performed in Eastern Switzerland, the damage threshold of plum sawflies (both species together) was 80-100 sawfly trap $^{-1}$ and it corresponded to ca. $8 \%$ of damaged fruits (Wildbolz, Staub, 1984). As could be seen from the results of our investigation, trap catches of 30 sawfly trap $^{-1}$ in 2010 and 70 sawfly trap ${ }^{-1}$ in 2011 resulted in infestation levels of $7.0 \%$ and $27.8 \%$, respectively, meaning plum sawfly density was lower than the defined economic threshold, the extent of damage was still high, especially in 2011. It suggests that both plum sawfly species are capable of causing severe damage even at lower densities if conditions are favourable and peak flight period coincides with flowering phase of certain cultivar. Furthermore, in years when mass flight is delayed compared to flowering phase, cumulative trap counts are not reliable parameter to predict percentage of infested fruits. In 2011, mass flight period of both sawfly species began before the flowering of cv. 'Stanley' and increase of population was gradual until the main flowering phase which in turn resulted in high infestation. Additionally, it could be stated that under the circumstances when mass flight coincides with susceptible flowering phase trap catch data could be reliably used to predict high fruit damage level.

Temperature sums for spring emergence. An effort was made to establish a temperature sum to predict spring emergence of first adults for both plum sawfly species. Several attempts were made to develop a forecasting models for $H$. minuta, but one of them was directed at predicting the possible severity of infestation in Ukrainian forest-steppe zone based on several environmental factors (Шевчук, Денисюк, 2009) and another was aimed at forecasting mass swarming period in Hungary based on soil temperatures at $5 \mathrm{~cm}$ depth and using lower thermal threshold of $10^{\circ} \mathrm{C}$ (Nagy, 1959). In this study, we tried to predict the appearance of first adult plum sawflies based on soil temperatures at $10 \mathrm{~cm}$ depth and using lower developmental threshold of $4^{\circ} \mathrm{C}$. The motivation to use temperatures measured at $10 \mathrm{~cm}$ depth was the fact that sawflies were reported to be found in the soil at 5-30 cm depths, so it is a more realistic measure to use in the model. Graf et al. (1996 a) in an experiment under controlled conditions established lower thermal threshold of $4^{\circ} \mathrm{C}$ for apple sawfly (H. testudinea) and this physiologically based threshold should also be applicable for closely related plum sawfly species. Results of our study demonstrated that in the case when lower threshold of $4^{\circ} \mathrm{C}$ was used as starting date for temperature sum accumulation, the emergence of first adult sawflies corresponded to $86 \pm 19$ degree-days for H. minuta and similar temperature sum but with slightly higher variation $-86 \pm 26$ degree-days for H. flava (Table 2).

When fixed date of 1 April was used as starting date, temperature sums of $84 \pm 17$ dd and 84 $\pm 26 \mathrm{dd}$ were calculated for H. minuta and H. flava, respectively. Significant differences in temperature sums were not detected when compared between fixed and physiologically based starting dates for temperature sum accumulation ( $F$-test, $\alpha>0.05$ ). Spring emergence of first adult sawflies of $H$. minuta sawfly in all three years differed at most by three days from calculated mean. Spring emergence of yellow plum sawfly was more variable and differed at most by five days from the mean emergence day (leap and non-leap years) during the study. A number of studies point out that overwintering sawfly larva break its diapause before the lower developmental threshold is reached, so it can begin its post-diapause development as soon as the temperature reaches the required value (Graf et al., 1996 a; Zijp, Blommers, 1997). In Lithuania, 
Table 2. Observed day-numbers at the day of the first sawfly capture, temperature sums accumulated each year and mean $( \pm \mathrm{SD})$ temperature sums (degree-days) at the day of first capture are presented

\begin{tabular}{|c|c|c|c|c|c|c|c|c|c|c|}
\hline & \multirow{3}{*}{ Year } & \multirow{3}{*}{$\begin{array}{c}\text { Day number } \\
\text { at the day of the } \\
1^{\text {st }} \text { capture }\end{array}$} & \multicolumn{8}{|c|}{ Temperature sums accumulation } \\
\hline & & & \multicolumn{4}{|c|}{ in soil, from $\mathrm{T} \geq 4^{\circ} \mathrm{C}$} & \multicolumn{4}{|c|}{ in soil, from 1 April } \\
\hline & & & $\begin{array}{c}\text { degree- } \\
\text { days }\end{array}$ & $\begin{array}{c}\text { mean- } \\
\text { day }\end{array}$ & $\begin{array}{c}\text { dd- } \\
\text { mean }\end{array}$ & $\begin{array}{l}\text { day- } \\
\text { mean }\end{array}$ & $\begin{array}{c}\text { degree- } \\
\text { days }\end{array}$ & $\begin{array}{c}\text { mean- } \\
\text { day }\end{array}$ & $\begin{array}{l}\text { dd- } \\
\text { mean }\end{array}$ & $\begin{array}{l}\text { day- } \\
\text { mean }\end{array}$ \\
\hline \multirow{4}{*}{$\begin{array}{l}\text { Hoplocampa } \\
\text { minuta }\end{array}$} & 2010 & 121 & 104 & 118 & 18 & 3 & 101 & 118 & 17 & 3 \\
\hline & 2011 & 116 & 67 & 118 & -19 & -2 & 67 & 118 & -17 & -2 \\
\hline & 2012 & 120 & 86 & 120 & 0 & 0 & 83 & 120 & -1 & 0 \\
\hline & Mean \pm SD & & $86 \pm 19$ & & & & $84 \pm 17$ & & & \\
\hline \multirow{4}{*}{$\begin{array}{l}\text { Hoplocampa } \\
\quad \text { flava }\end{array}$} & 2010 & 123 & 115 & 118 & 29 & 5 & 114 & 118 & 30 & 5 \\
\hline & 2011 & 117 & 75 & 118 & -11 & -1 & 75 & 118 & -9 & -1 \\
\hline & 2012 & 118 & 67 & 120 & -19 & -2 & 64 & 120 & -20 & -2 \\
\hline & Mean \pm SD & & $86 \pm 26$ & & & & $84 \pm 26$ & & & \\
\hline
\end{tabular}

Note. For each temperature sum day numbers (mean day) and differences between observed and mean (dd-mean) for temperature sums and (day-mean) for day numbers are presented.

the moment soil temperatures usually reach $4^{\circ} \mathrm{C}$ can vary significantly around 1 April. Therefore, choice of thermal threshold as starting point for temperature sum calculation could be more practical than the fixed starting date, as it would be more reliable when used for different localities. On the other hand, calculated temperature sums exhibited slightly smaller variation when fixed starting date was used. Additionally, use of fixed starting date for calculations would be less difficult as user of meteorological station or advisory pest forecasting service worker would not have to check soil temperatures every day and simply would start calculations from 1 April. In our opinion, though, in order to obtain reliable temperature sums calculated from 1 April, more years in different localities of the study are needed. Nevertheless, temperature sum model to predict emergence of first adult plum sawflies is a useful tool for more accurate timing of trap installation in the orchard. We propose temperature sum of 60 degree-days as a provisionary date for trap placement in the orchards.

\section{Conclusions}

1. Both plum sawfly species Hoplocampa minuta and $H$. flava are equally important pests of plums with $H$. minuta constituting $60 \%$ and being slightly dominant and, considering various population parameters (emergence and flight dynamics, population density, sex ratio) being more significant contributor to fruit damage.

2. Coincidence between mass flight and flowering periods is one of the major factors influencing fruit damage caused by plum sawflies. When mass flight coincides with flowering phase vulnerable to sawfly attack of certain cultivar, high damage should be anticipated even at lower population densities.

3. Direct correlation between Rebell ${ }^{\mathbb{R}}$ bianco white sticky trap catches and infestation level was determined under the circumstances when mass flight coincided with susceptible flowering phase. In such case, trap catch data could be reliably used to predict magnitude of fruit damage level $(r=0.630, p<0.001)$.
4. Two dates to begin calculations of temperature sums to predict emergence of first plum sawflies were proposed - fixed date at 1 April or moment when soil temperature at $10 \mathrm{~cm}$ depth reaches $4^{\circ} \mathrm{C}$ for the first time. Provisionary date at temperature sum of 60 degree-days is proposed for trap placement in the orchards.

\section{Acknowledgments}

The paper presents research findings, obtained through the long-term research programme "Harmful organisms in agro and forest ecosystems (KOMAS)" implemented by Lithuanian Research Centre for Agriculture and Forestry.

Received 20032013

Accepted 03092013

\section{References}

Andreev R., Kutnikova H. 2010. Possibility of reducing chemical treatments aimed at control of plum insect pests. Acta Horticulturae (ISHS), 874: 215-220

Arnaoudov V., Andreev R. 2002. A study on carpophagous Hymenoptera and Lepidoptera of plums in the Plovdiv fruit-growing region. Acta Horticulturae (ISHS), 577: $247-253$

Blaisinger P. 1974. A trapping technique based on colour attractivity in plum sawflies: Hoplocampa flava L. and Hoplocampa minuta Christ. Zeitschrift für Angewandte Entomologie, 77 (1-4): 353-357 (in German)

Boller E., Prokopy R. J. 1976. Bionomics and management of Rhagoletis. Annual Review of Entomology, 21: 223-246 http://dx.doi.org/10.1146/annurev.en.21.010176.001255

Bovien P., Stapel C. 1940. Experiments on the control of the plum sawfly, H. minuta. Tidsskrift for Planteavl, 44: 699730 (in Danish)

Caruso S., Cera M. C. 2004. Control strategies for plum sawflies (Hoplocampa flava, Hoplocampa minuta) in organic farming. IOBC/WPRS Bulletin, 27 (5): 107-111 
Ciglar I., Barić B. 2002. Monitoring the appearance and possibility for prevention of the apple sawfly in Croatia Journal of Pest Science, 75: 41-45 http://dx.doi.org/10.1046/j.1439-0280.2002.02013.x

Graf B., Höhn H., Höpli H. U. 1996 (a). The apple sawfly, Hoplocampa testudinea: a temperature driven model for spring emergence of adults. Entomologia Experimentalis et Applicata, 78: 301-307 http://dx.doi.org/10.1111/j.1570-7458.1996.tb00794.x

Graf B., Höhn H., Höpli H. U. 1996 (b). Optimizing the risk assessment for the apple sawfly Hoplocampa testudinea Klug (Hymenopter, Tenthredinidae). IOBC/WPRS Bulletin, 19: 113-117

Graf B., Höhn H., Höpli H. U. 2001. The apple sawfly, Hoplocampa testudinea: temperature effects on adult lifespan and reproduction. Entomologia Experimentalis et Applicata, 98: 377-380 http://dx.doi.org/10.1046/j.1570-7458.2001.00795.x

Graf B., Höpli H. U., Höhn H. 2002. The apple sawfly, Hoplocampa testudinea: egg development and forecasting of egg hatch. Entomologia Experimentalis et Applicata, 105: 55-60 http://dx.doi.org/10.1046/j.1570-7458.2002.01032.x

Hadzistevic D. 1959. The existence of several years diapause in the plum sawflies (H. minuta and H. flava) in the Sarajevo region. World Congress of Agricultural Research. Rome, Italy, p. 1371-1376

Jaastad G., Røen D., Bjotveit E., Mogan S. 2007. Pest management in organic plum production in Norway. Acta Horticulturae (ISHS), 734: 193-199

Jaworska M. 1992. Biological control of Hoplocampa testudinea Klug (Hymenoptera, Tenthredinidae). Acta Phytopathologica et Entomologica Hungarica, 27: 311-315

Kuenen D. J., van de Vrie M. 1951. Observations on the biology and control of the apple sawfly (Hoplocampa testudinea Klug, Hymenopt., Tenthredinidae). Tijdschrift over Plantenziekten, 57: 135-157 (in Dutch)

Leski R. 1960. Studies on the bionomics of plum sawflies (H. minuta and H. flava). Rocznik nauk rolniczych, 81 (2): 441-464 (in Polish)

Meier U. H. 1997. Growth stages of mono- and dicotyledonous plants: BBCH. Berlin, Germany, 622 p.

Molinari F., Carli G., Pari P. 1996. First note on plum sawflies in Emilia Romagna (Northern Italy). Acta Horticulturae (ISHS), 422: 370-371

Nagy B. 1959. Possibilities of forecasting the date of the swarming of plum sawflies. A övényvédelem időszerü kérdései, 1 (2): 48-57 (in Hungarian)

Niezborala E. 1978. Studies on the biology of the apple sawfly (Hoplocampa testudinea Klug). Prace Instytutu Sadownictwa i Kwiacarstwa, Series A, 20: 201-210

Oroian I., Oltean I., Odagiu A., Paulette L., Iederan C., Brasovean I. 2009. The control and monitoring of the orchard pests in Transylvania. Research Journal of Agricultural Science, 41 (1): 277-283

Owens E. D., Prokopy R. J. 1978. Visual monitoring trap for European apple sawfly. Journal of Economic Entomology, 71: $576-578$

Rabbinge R. 1976. Biological control of fruit-tree red spider mite: Ph. D. thesis, Agricultural University, Wageningen, the Netherlands
Rozpara E., Badowska-Czubik T., Kowalska J. 2010. Problems of the plum and cherry plants protection in ecological orchard. Journal of Research and Applications in Agricultural Engineering, 55 (4): 73-75

Southwood T. R. E., Henderson P. A. 2000. Ecological methods ( $3^{\text {rd }}$ ed.). Oxford, UK, 575 p.

Stanionytė A., Zajančkauskas P. 1970. Lithuanian insect fauna of plums. Acta Entomologica Lituanica, 1: 73-81 (in Lithuanian)

Tauber M. J., Tauber C. A. 1976. Insect seasonality: diapause maintenance, termination, and postdiapause development. Annual Review of Entomology, 21: 81-107 http://dx.doi.org/10.1146/annurev.en.21.010176.000501

Wildbolz T., Staub A. 1984. Supervision of sawflies by checking the egg laying, the infestation and with the use of white traps. Schweizerische Zeitschrift für Obst- und Weinbau, 120: 228-232 (in German)

Zar J. H. 2010. Biostatistical Analysis (5 ${ }^{\text {th }}$ ed.). Pearson Education. Upper Saddle River, New Jersey, 944 p.

Zijp J. P., Blommers L. H. M. 1997. Prediction of flight of apple sawfly, Hoplocampa testudinea, using temperature sums. Entomologia Experimentalis et Applicata, 84 (1): 71-75 http://dx.doi.org/10.1046/j.1570-7458.1997.00199.x

Zijp J. P., Blommers L. H. M. 2002. Impact of the parasitoid Lathrolestes ensator (Hym., Ichneumonidae, Ctenopelmatinae) as antagonist of apple sawfly Hoplocampa testudinea (Hym., Tenthredinidae). Journal of Applied Entomology, 126: 366-377 http://dx.doi.org/10.1046/j.1439-0418.2002.00666.x

Шевчук И. В., Денисюк А. Ф. 2009. Имитационная модель динамики численности имаго черного сливового пилильщика (Hoplocampa minuta Christ.) в зависимости от погодных факторов в зоне северной лесостепи Украины. Вестник защиты растений, 3: 67-71 
ISSN 1392-3196 / e-ISSN 2335-8947

Zemdirbyste-Agriculture, vol. 101, No. 1 (2014), p. 91-100

DOI 10.13080/z-a.2014.101.013

\title{
Slyvinių pjūklelių Hoplocampa minuta ir H. flava rūšiụ santykis, pasirodymas pavasarị, populiacijų dinamika ir žalingumas slyvų sode
}

\author{
R. Tamošiūnas, A. Valiuškaitè, E. Survilienè, N. Rasiukevičiūtè
}

Lietuvos agrariniu ir mišku mokslų centro Sodininkystès ir daržininkystės institutas

\begin{abstract}
Santrauka
Juodojo slyvinio pjūklelio Hoplocampa minuta (Christ, 1791) ir geltonojo slyvinio pjūklelio Hoplocampa flava (Linnaeus, 1761) populiacijų tyrimai atlikti LAMMC Sodininkystès ir daržininkystės instituto slyvyne 20102012 m. Tirta galimybė prognozuoti H. minuta ir $H$. flava suaugèlių skraidymo pradžią efektyviụjų temperatūru sumos modeliu. Slyvinio pjūklelio rūšiu santykis, skraidymo terminai, santykinis gausumas ir gausumo dinamika nustatyta baltos spalvos lipniosiomis gaudyklèmis Rebell ${ }^{\mathbb{E}}$ bianco. H. minuta labiau dominavo dvieju rūšiu komplekse: tyrimu metu šios rūšies individai slyvų sode sudare $62 \%$, lyginant su $H$. flava. İvertinus ịvairius populiacijų rodiklius - skraidymo pradžią ir dinamiką, populiacijų tankị, lyčių santykị - nustatyta, kad juodasis slyvinis pjūklelis yra žalingesnis slyvų kenkejjas Vidurio Lietuvos agroklimato sąlygomis. Populiacijų tankis ir skraidymo dinamika yra svarbūs veiksniai, turintys ịtakos potencialiam slyviniu pjūklelių žalingumui. Masinio skraidymo ir žydẻjimo laikotarpio sutapimas yra vienas pagrindinių veiksnių, lemiančių slyvinio pjūklelio pažeistu vaisių užuomazgų kiekị. Kai šie laikotarpiai sutapo, užfiksuotas didelis $(27,8$ \%) slyvinio pjūklelio žalingumas. Kai masinis skraidymas buvo uždelstas, lyginant su žydèjimu, žalingumas buvo mažas (7 \%). Koreliaciné analizė parodè, kad remiantis lipniosiomis gaudyklèmis pagautu pjūkleliu kiekiu, tikètiną žalingumą galima esmingai prognuozuoti tik tuo atveju, jei skraidymo ir žydėjimo laikotarpiai sutampa. Siekiant prognozuoti abiejų rūšiu pirmujų suaugèliụ pasirodymą, nustatyta efektyviưjų temperatūrų suma, paremta dirvožemio temperatūra $10 \mathrm{~cm}$ gylyje ir dviem skirtingomis skaičiavimų pradžios datomis. Pirmụjų saugèlių pasirodymo galima tikètis temperatūrų sumai pasiekus 86 arba $84{ }^{\circ} \mathrm{C}$, priklausomai nuo pradinès skaičiavimo datos. Taip pat pasiūlyta rekomendacinè $60^{\circ} \mathrm{C}$ temperatūrų suma, kurią pasiekus gaudyklès iškabinamos soduose.
\end{abstract}

Reikšminiai žodžiai: baltos lipniosios gaudyklès, populiacijų dinamika, slyvinis pjūklelis, temperatūrų sumos modelis. 